\title{
アルミニウム投与がモルモット内耳電 気現象（EP）に及ぼす影響の検討
}

1. 緒言

アルミニウム $(\mathrm{Al})$ は地殼中に, 酸素, ケイ素に次 いで第 3 番目に豊富な元素であるが極めて反応性が高 いために自然界では，ケイ酸アルミニウム $\left(\mathrm{KAlSi}_{3}\right.$ $\left.\mathrm{O}_{8}\right)$ ，または，ボーキサイトの形で存在し，元素のみの 形では殆ど存在しない。そのために金属としての $\mathrm{Al}$ は現在広く用いられている金属の中では，比較的その 使用の歴史は浅く, その生体影響の研究も, 近年, 漸 く注目されはじめたところである。

今日, $\mathrm{Al}$ の生体への影響として, 透析脳症 ${ }^{11}$ Alzheimer 病 ${ }^{2)}$ などの中枢神経系疾患や, 透析骨症 ${ }^{3)}$, 及び, 制酸剤の長期連用による骨障害 ${ }^{4}$ などの発症因子とし ての可能性が考えられている。

また，大気污染に起因する酸性雨のために土壌中の $\mathrm{Al}$ が溶出し, 河川, 沼湖中の $\mathrm{Al}$ 濃度が上昇し, それ によると考えられる生体系への影響 れている。

このような $\mathrm{A} 1$ の生体影響発現のメカニズムは, 現 在のところ不明であるが，そのメカニズムの一つとし て， $\mathrm{Al}$ の生体エネルギー代謝に及ぼす影響677 が考え られている。

解糖系の第一段階の反応にかかわる醉素である hexokinase は glucose と ATP から,リン酸エステルで ある glucose-6-phosphate を作るが，この反応におい て ATPは Mg-ATPの形でのみ反応性を有する。Al は,この様な $\mathrm{Mg}$-dependent な酵素反応系において酵 素作用を受けない Al-ATP を生じることにより, 反応 を抑制することが知られている7。

内耳に扔いて重要な役割を担っている $\mathrm{Na}-\mathrm{K}$ -ATPaseも, その反応基質は Mg-ATPであり, hexokinase と同じ Mg-dependent な酵素であるた め, $\mathrm{Al}$ の,この酵素に対する抑制効果が推測される。
札幌医科大学公衆衛生学教室

貞本 晃一, 前原 直樹, 山村晃太郎

また, $\mathrm{Al}$ のエネルギー代謝に及ぼす間接的影響とし て, $\mathrm{Al}$ が経口投与された場合のリンの吸収障害により 低リン血症が, 生体内の ATP の低下を引き起すこと も報告 ${ }^{8121213)}$ されている。

一方，腎不全患者や，人工血液透析患者では内耳障 害が高率にみられ, 腎不全や人工透析と内耳機能との 関連が, 近年, 注目されている。腎不全, 及び人工透 析に伴う難聴の内耳病変は血管条を中心に存在するこ とが報告 ${ }^{9)}$ され，実験的腎不全動物で，内耳血管条の Na-K-ATPase の活性が低下していることが報告 ${ }^{10}$ されている。

著者らは, 今回の実験で, in vitroでみられる $\mathrm{Al} の$ エネルギー代謝に及ぼす影響が，はたして生体内で見 られるか否かを，モルモットの内耳電気現象を観察す ることにより検討し，多少の知見を得たのでここに報 告する。

\section{2. 方法}

\section{1）予備実験}

$\mathrm{Al}$ が, in vitro で, hexokinase でみられるような $\mathrm{Mg}$ -dependent な䤃素に対する抑制作用が Na-K-ATP. ase でみられるか否かをみるために in vitroの実験を した。

medium は, Na $85 \mathrm{mM}, \mathrm{K} 30 \mathrm{mM}, \mathrm{Mg} 0.01 \mathrm{mM}$, ATP $0.1 \mathrm{mM}$ 及び, buffer は Tris- $\mathrm{HCl} 50 \mathrm{mM}$ pH7.5 で調整した。Na-K-ATPase はSigma 社製を用いた。 $38^{\circ} \mathrm{C} 30$ 分間 incubate した後, $10 \%$ TCA で除蛋白, $3000 \mathrm{rpm}$ で 5 分間遠心分離し, その上清の無機リンを Allen 法で定量した。

2) $\mathrm{Al}$ 負荷条件

プライエル反射正常な, 体重 250 350g の白色モル モット雄30匹を使用し, $\mathrm{Al}$ 負荷条件を以下の 3 群, 各 10匹とした。 
第 1 群；( $\mathrm{Al}$ の腹腔内投与と経口投与の併用群) 腹 腔内投与：0.5\%アルミニウム溶液を乳酸アルミニウ ムを用いて作成し, $10 \mathrm{~N} \mathrm{NaOH}$ にて pH7.5 に調整， 1 日 1 回, 0.5 $2 \mathrm{ml}$ を腹腔内注射し, totalで, $\mathrm{Al}$ とし て $80 \mathrm{mg}$ を21日間で投与した。

経口投与：モルモット用標準飼料に塩化アルミニウ ムを $2 \%$ 混入し，21日間自由摂取させ，また，飲料水 は水道水を自由捸取させた。

第 2 群；(腹腔内投与のみの群)

腹腔内投与 ; 第 1 群と同じ $0.5 \%$ アルミニウム溶液 を用いて, 0.5 3ml を $2 \sim 3$ 回/週注射し, Al として total $150 \mathrm{mg}$ を28日間で投与した。飼育は, モルモット 用標準飼料を自由捸取させ，飲料水は水道水を自由攝 取させた。

第 3 群； (control 群)

第 1 , 第 2 群と同一週齢のモルモットをモルモット 用標準飼料，及び水道水にて飼育した動物を使用した。

3）電気生理実験

nembutal を $0.5 \mathrm{ml} / \mathrm{kg}$ 体重の腹腔内注射により麻 酔し, 特製金属固定器を用い背位で頭部を固定, 型の ごとく中耳骨胞を開放し, 蝸牛全回転を視野下におい た。

次いで気管切開を施し，挿管後, succin $2 \%$ 注射液 $0.6 \mathrm{ml} / \mathrm{kg}$ 体重筋注し, 自発呼吸を止め, 人工呼吸器に 接続した後, 双眼顕微鏡下に蝸牛基礎回転中央階側壁 の骨壁を特殊メスで削って薄くし, 次いで, 尖刀にて 直径数ミクロンの小孔を穿った。蝸牛中央階に $3 \mathrm{MK}$ $\mathrm{Cl}$ 充填ガラス管電極を刺入して EP (endochoclear potential) を導出し, デジタルボルトメータにて観察 する一方,ペンレコーダで EP を記録した。電位が安定 後, レスピレーターを止めることにより anoxia を 3 分間負荷し, 30 秒ごとの $\mathrm{EP}$ 電位の変化を観察した。

4）血清 Al, 血清無機りン, 血液中 ATP 值の測定 3)の電気生理実験終了後,ただちに断頭にて採血し, 血液 $1.0 \mathrm{ml}$ を ATP 測定 (ベーリンガー・マンハイム社 製 $\mathrm{ATP}$-test）に用い残りを血清分離後マイナス $20^{\circ} \mathrm{C}$ にて保存, 全実験終了後, 一括して血清無機リン, 及 び血清 $\mathrm{Al}$ を定量した。血清無機りンはAllen 法にて 定量, 血清 $\mathrm{Al}$ はフレームレス原子吸光法 ${ }^{11)}$ にて測定 した。

\section{3 結 果}

1）予備実験

結果を図- 1 に示す。縦軸は control に対する各 $\mathrm{Al}$
濃度における Na-K-ATPaseの活性を百行率で現 し, 横軸は $\mathrm{Al}$ 濃度である。 3 回の実験の結果の平均 で, $\mathrm{Al}$ 濃度が $10^{-5}$ モルのとき約 $25 \%, 10^{-4}$ モルで約 3 $5 \%, 10^{-3}$ モルで約 $80 \%$ Alによる, Na-K-ATPase に対する in vitroでの抑制がみられた。

\section{2） $\mathrm{Al}$ 負荷動物}

$\mathrm{Al}$ 負荷期間中のモルモットの体重の変化は負荷前 の体重が第 1 群では $283 \pm 40 \mathrm{~g}(\mathrm{~N}=10)$, 第 2 群では $296 \pm 25 \mathrm{~g}(\mathrm{~N}=10)$ で, 負荷終了後の体重は, 第 1 群で は $230 \pm 29 \mathrm{~g}(\mathrm{~N}=7)$, 第 2 群では $342 \pm 71 \mathrm{~g}(\mathrm{~N}=7)$ で あった。投与期間中に第 1 群では 2 匹, 第 2 群では 3 匹が死亡している。また，中耳炎のため実験不能の動 物が第 1 群で 1 匹, 第 3 群で 1 匹いた。以上のような, 投与期間中の動物の消耗や実験の不成功のため, 各群 10 匹中データが得られた数は第 1 群が 7 匹, 第 2 群が 7 匹, control 群が 8 匹であった。

3) 内耳電気生理実験

結果を図- 2, 及び表- 1 に示す。図-2では, 縦軸は $\mathrm{EP}(\mathrm{mV})$, 横軸は, 3 分間の窒息による anoxia 負荷 の時間(分) である。表- 1 は, anoxia 負荷後30秒毎の $\mathrm{EP}$ 值と, anoxia 負荷後 $\mathrm{EP}$ 值が $0 \mathrm{mV}$ に達するまで の時間 (秒) 及び 3 分間の anoxia で示した EP の最小 值とを示す。図-2で示すように $\mathrm{Al}$ 負荷動物群では control の EP 值に比較して anoxiaによるEPの減少 経過が遅延していた。表-1で示すごとく, control 群 と第 1 群の間では, 窒息開始後, 1 分, 1 分 30 秒, 2 分, 2 分 30 秒, 及び 3 分で $\mathrm{EP}$ の值に有意差を認め, control 群と第 2 群の間でも, 窒息開始後, 1 分から 2

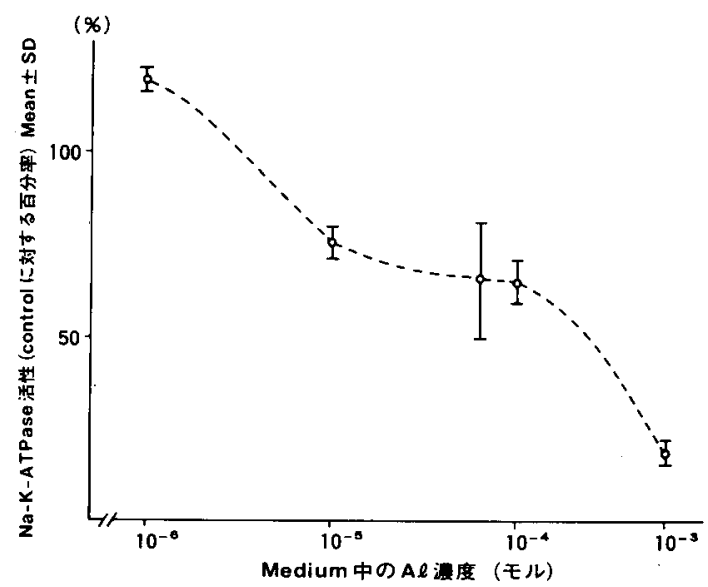

図-1 Na-K-ATPaseに対する $\mathrm{Al} の$ in vitroでの 影響 
表- 13 分間の Anoxia 負荷における EP 值の変化

\begin{tabular}{|c|c|c|c|c|c|c|}
\hline & & control $(N=8)$ & 第 1 群（N= & $=7)$ & 第 2 群 ( $N=$ & $=7)$ \\
\hline 前値 & $(m V) \pm S D$ & $78.8 \pm 5.3$ & $81.6 \pm 3.5$ & & $77.3 \pm 3.9$ & \\
\hline 30秒值 & $(m V) \pm S D$ & $75.3 \pm 7.9$ & $81.5 \pm 3.6$ & & $77.6 \pm 4.1$ & \\
\hline 1 分 & $(m V) \pm S D$ & $34.0 \pm 14.8$ & $71.4 \pm 9.1$ & $※ ※$ & $65.0 \pm 9.5$ & $※ ※$ \\
\hline 1 分30秒 & $(m \mathbf{m}) \pm \mathrm{SD}$ & $1.2 \pm 10.3$ & $40.1 \pm 5.6$ & $※ ※$ & $29.3 \pm 16.2$ & $※ ※$ \\
\hline 2 分 & $(m V) \pm S D$ & $-12.8 \pm 8.7$ & $13.7 \pm 8.5$ & $※ ※$ & $3.5 \pm 14.0$ & ※ \\
\hline 2 分 30 秒 & $(m V) \pm S D$ & $-23.4 \pm 7.3$ & $-3.7 \pm 6.1$ & $※ ※$ & $-9.3 \pm 14.1$ & ※ \\
\hline 3 分 & $(m V) \pm S D$ & $-30.9 \pm 6.1$ & $-14.3 \pm 6.4$ & $※ ※$ & $-18.0 \pm 12.8$ & \\
\hline 最小値 & $(m V) \pm S D$ & $-32.7 \pm 5.6$ & $-19.3 \pm 8.1$ & $※ ※$ & $-21.9 \pm 12.7$ & \\
\hline \multicolumn{2}{|c|}{$O m V$ 到達時間 (秒) $\pm S D$} & $94.6 \pm 17.1$ & $142.6 \pm 12.3$ & ※ & $132.0 \pm 31.3$ & ※ \\
\hline
\end{tabular}

※： control との間に $\mathbf{P}<0.05$ で有意差有り (T-test) ※: " $P<0.01$ "

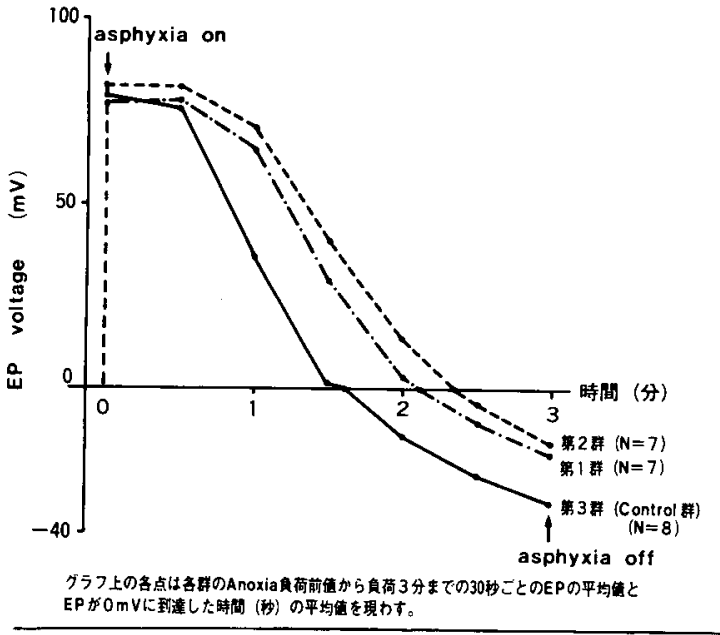

図-2 3 分間の Anoxia 負荷による EP 值の変化

分30秒までの間で $\mathrm{EP}$ 值に有意差を認めた。

また，窒息負荷後 $\mathrm{EP}$ 值が $0 \mathrm{mV}$ まで低下するのに 要した時間を比較すると control 群と第 1 群, 及び control 群と第 2 群の間に有意差を認めた。 3 分間の 窒息の負荷での EP の最小值の比較では, control 群と 第 1 群の間に有意差を認め, 第 2 群では control に比 較して EP 值が高い傾向がみられた。

また, 第 1 群と第 2 群の間での 3 分間の anoxia 負 荷による $\mathrm{EP}$ の動態では，どの時間でも $\mathrm{EP}$ 值に有意 差を認めなかった。
4）血清 $\mathrm{Al}$, 血清無機リン, 及び血液中 ATP 值 結果を図-3-1，2，3に示す。図-3-1では各群 の血清 $\mathrm{Al}$ 濃度 $(\mathrm{ppb})$ を示し, 図-3-2では血清無機 リン $(\mathrm{mg} / \mathrm{dl})$, 図-3-3では血液中 ATP $(\mathrm{mg} / \mathrm{dl})$ を 示す。血清 $\mathrm{Al}$ 濃度は, 第 1 群, 第 2 群の $\mathrm{Al}$ 負荷群で は control 群に比して約100倍の濃度を認めた。しか し, 第 1 群と第 2 群の間には血清 $\mathrm{Al}$ 濃度の間に有意 差はみられなかった(図-3-1)。血清無機リン值は第 1 群, 第 2 群共に control 群に比較して有意な低下が みられた (図-3-2) 血液中の ATP 值は第 1 群のみで control との間に有意差がみられた（図-3-3)。

\section{4 考察}

$\mathrm{Al}$ の生体エネルギー代謝に及ぼす間接的影響とし て, 経口投与された $\mathrm{Al}$ は消化管内でリンと反応して 不溶性のリン酸アルミニウムを生じ，そのためにリン の吸収を阻害することが言われている ${ }^{12)}$ 。この様な $\mathrm{Al}$ の性質より, $\mathrm{Al}$ は腎不全患者の高リン血症の予防の目 的で投与されているが，この様な腎不全の患者で， $\mathrm{Al}$ が過剰に投与されると，かえって低リン血症が生じ， そのために血中の ATP が低下することが報告 ${ }^{13)} さ れ$ ている。

今回の実験でも, $\mathrm{Al}$ の経口投与を腹腔内投与と併用 している第 1 群では, 血清無機リンと, 血中 ATP の有 意な減少がみられた。 $\mathrm{Al}$ の腹腔内投与のみの第 2 群に おいても血清無機リンの有意な低下がみられた。経口 
投与以外の経路で投与された $\mathrm{Al}$ が血清無機りンの減 少を引き起したとの報告は他にみられな゙いが，腹腔内 に投与され，吸収された $\mathrm{Al}$ の一部は胆汁中に排せつ ${ }^{14)}$ され，それが経口投与された $\mathrm{Al}$ と同じメカニズムで 血清無機りンを低下させている可能性も考えられる。

次に, $\mathrm{Al}$ のエネルギー代謝に及ぼす直接的影響とし て, $\mathrm{Al}$ が, hexokinase 等の $\mathrm{Mg}$-dependent な酵素に 対し抑制効果を有する事が報告されているが，同じ $\mathrm{Mg}$-dependent な酵素である Na-K-ATPase に対し ても $\mathrm{Al}$ は抑制作用を有する可能性が考えられる。そ こで，著者らは内耳電気生理実験に先行して予備実験 を行い, $\mathrm{Al}$ が in vitroで $\mathrm{Na}-\mathrm{K}-\mathrm{ATPase}$ に対し抑制 的効果を有する事を認めた。

さて, Kuijpers ${ }^{15)} ら は$ ouabain で抑制される内耳血 管条の Na-K-ATPase と EP の動態が同一割合で変

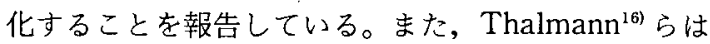
anoxia の負荷により血管条の ATP, Pcr (phosphocreatinine)が低下し，それと平行して EP 電位が低下す ることを報告している。

この様に, 内耳の電位が ATP の代謝と密接な関係
がある事はほぼ認められているが, Marcus ら ${ }^{17)}$ は, 金 属で Na-K-ATPase の特異的inhibitor であるバナジ ウムの内耳外リンパ灌流後, anoxia の負荷によって EP の減少経過の遅延がみられたと報告している。ま た, Thalmann ら ${ }^{16)}$ は, 同様に Na-K-ATPase を抑制 することが知られている loop 利尿剤の静脈内投与後 に anoxia を負荷すると, EP の減少経過の遅延がみら れることを報告している。

即ち, Na-K-ATPase 活性が抑制されている内耳で は, anoxia 負荷による EP 值は, 正常な内耳に比較し て，その減少経過が遅延することが言われている。

in vitroで $\mathrm{Al}$ が， Na-K-ATPase に対して抑制的 に作用すること, 及び，バナジウムやloop 利尿剤など の Na-K-ATPase を抑制することが知られているも のの投与後に anoxia を負荷すると EP の減少経過に 遅延が見られることなどより, $\mathrm{Al}$ 負荷動物における, anoxia 負荷時の EP 值の減少経過の遅延は, $\mathrm{Al}$ が, 内 耳で Na-K-ATPase を抑制することを推論させうる ものと思われる。

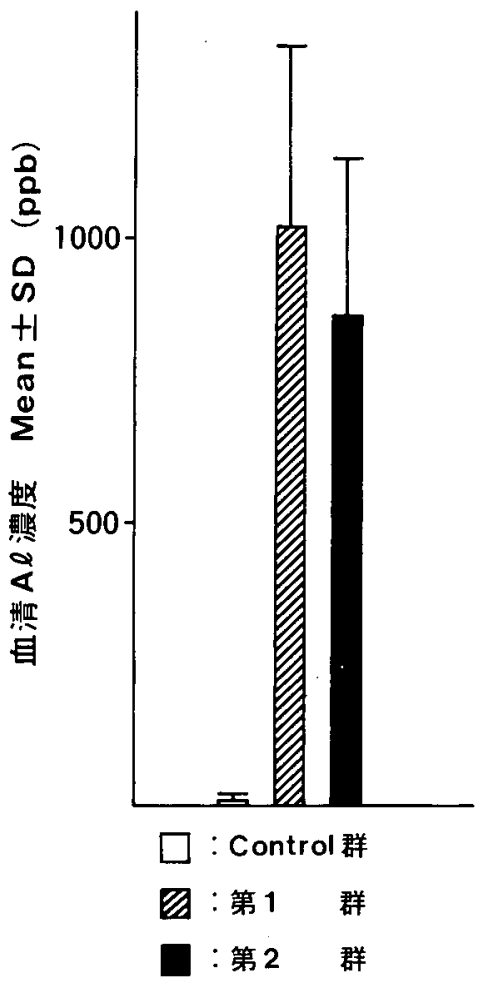

図-3-1

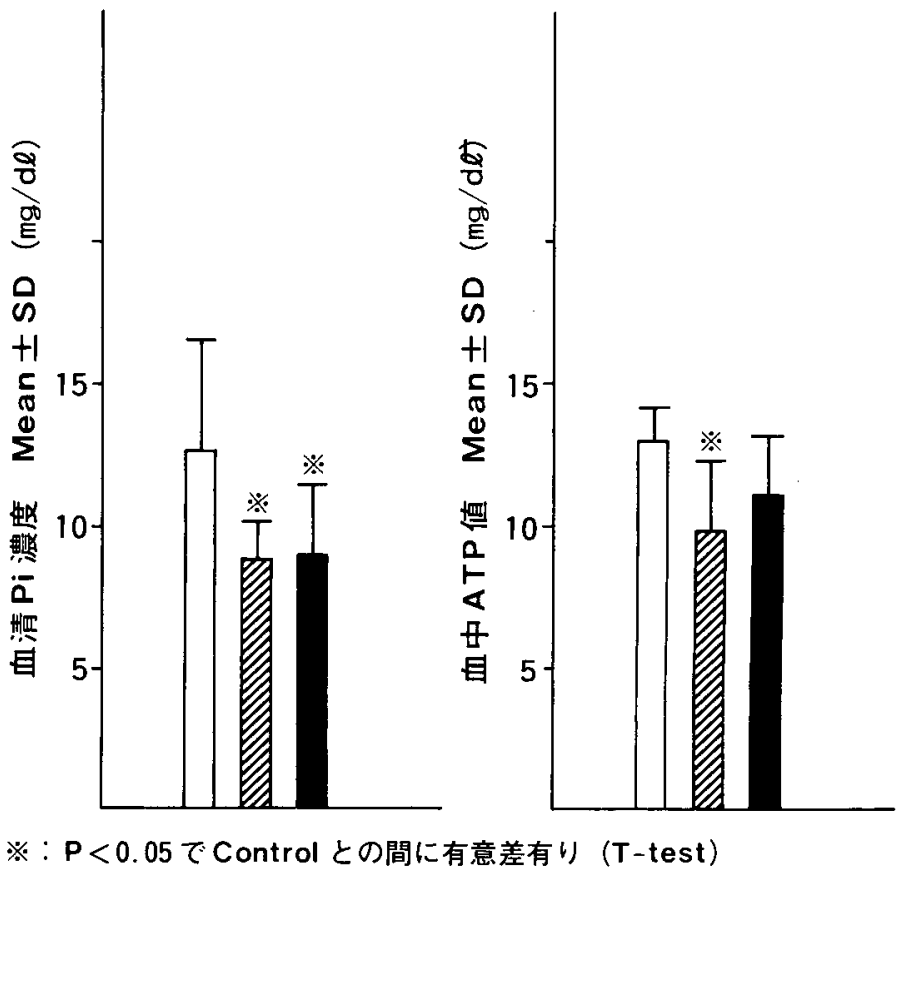

図-3-2
図-3-3 


\section{5 結 論}

プライエル反射正常なモルモット雄30匹を用い，各 群10匹の 3 群に分け, 第 1 群は $\mathrm{Al}$ の腹腔内投与と経 口投与の併用群, 第 2 群は腹腔内投与のみの群, 第 3 群を control 群とし内耳電気生理実験 (EP), 及び, 血 清 $\mathrm{Al}$, 血清無機リン, 血液中 ATP の測定をした。

第 1 群, 第 2 群の, $\mathrm{Al}$ の負荷群では, control に比し て, anoxia 貧荷によるEP 值の減少経過の遅延がみら れた。

生化学的測定では, 第 1 群, 第 2 群の $\mathrm{Al}$ 負荷群で は, control の約100倍の血清 AI 濃度を認め, 第 1 群で は, 血清無機リン值, 及び, 血液中 ATP 值が control 群に比して有意な減少を示し, 第 2 群では, 血清無機 リンで，controlに比して有意な低下を認めた。

\section{謝辞}

内耳電気生理実験に関する技術的指導と内耳機能に 関する多くの貴重なコメントをいただいた大阪鉄道病 院耳鼻科主任医長 菅野 亨先生に深く感謝いたしま す。

\section{Effect of Aluminum on Endocochlear Poten- tial of Guinea Pig}

T.Sadamoto, N.Maehara, K.Yamamura (Department of Public Health, Sapporo Medical College)

The experiments were performed on following three groups of guinea pigs with normal Preyer reflex.

Group 1 animals were fed with diet containing $2 \%$ aluminum chloride and given daily intraperitoneal injections of $0.5 \%$ elemental aluminum solution prepared by aluminum lactate. Group 2 animals were given 2-3 times a week intraperitoneal injections of the same solution used in group 1 .

Group 3 animals were untreated by aluminum (control).

The following results were obtained;

1) In group 1, group 2, aluminum treated groups, it was observed that the time course of decline of EP by anoxia delayed significantly compared with group 3 (control).

2) Serum aluminum concentrations in group 1 and 2 elevated 100 times of control.

3) Serum inorganic phosphorus concentrations of group 1 and 2 were decreased significantly.

4) Blood ATP level of group 1 also decreased significantly.

The delay of decline time course of EP by anoxia in the aluminum treated animals might be caused by the inhibition of Na-K-ATPase by aluminum in vivo.

\section{女献}

1) Alfrey, A.C., Le Gendre, G.R., and Kaehny, W. D.:The dialysis encephalopathy syndrome. Possible aluminum intoxication. N. Engl. J. Med., 294 ; 184-188, 1976.

2) Crapper, D.R., Krishnan, S.S., and Dalton A.J.: Brain aluminum distribution in Alzheimer's disease and experimental aluminum neurofibrillary degeneration. Science,180 ; 511-513, 1973

3) Platts, M.M., Goode, G.G., and Hislop, J.S.: Composition of the domestic water supply and the incidence of fractures and encephalopathy in patients on home dialysis. Brit. Med. J., 2; 657-660, 1977.

4) Cooke, N., Teitelbaumm, S. and Avioli. L.V.: Antacid-induced osteomalacia and nephrolithiasis. Arch. Intern. Med., 138 ; 1007-1009, 1978.

5) Niholm, N.E.I.: Evidence of involvement of aluminum in causation of defective formation of eggshells and of impaired breeding in wild passerine birds. Environmental Research, 26 ; 363-371, 1981.

6) Harrison, W.H., Godd, E., and Grey. R.M.: Aluminium inhibition of hexokinase. The Lancet 2 ; 277, 1972.

7) Trapp, G.A.:Studies of aluminum interaction with enzymes and proteins. The inhibition of hexokinase. Aluminum Neurotoxicity Pathotox Publishers, INC.1980.

8) Bishop, C.Williams, C., and Rodbard, S.:Diminished ATP levels induced in the chick by dietary aluminum hydroxide gel.J.Appl. Physiol., 14(2); 259-260, 1959.

9) Oda, M., Preciado, M, Quick, C.A., and Paparel- 
la, M.M.:Labyrinthine pathology of chronic renal failure patients treated with hemodialysis and kidney transplantation. Laryngoscope, 84 ; 1489-1506, 1974.

10) Adler, D., Fiehn, W., and Ritz, E.:Inhibition of $\mathrm{Na}-\mathrm{K}$-stimulated ATPase in the cochlea of guinea pig. Acta Otolaryngol., 90 ; 55-60, 1980.

11) Alderman, F.R., and Gitelmam, H.J.: Imporoved electrothermal determinatin of aluminum in serum by atomic absorption spectroscopy. Clin. Chem., 25(2) : (22) : 258-260, 1980.

12) Ondreiĉka, R., Ginter, E., and Kortus, J.:Chronic toxicity of aluminum in rat and mice and its effects on phosphorus metabolism. Brit.J.Ind. Med., 23 ; 305-312, 1966.

13) Lichtman, M.A., Miller, D.R., and Freeman, R. B.: Erythrocyte adenosine triphosphate deplation during hypophosphataemia in a uremic subject. $\mathrm{N}$.
Engl.J.Med., 280 ; 240-244, 1969.

14) Andersen, K.J., Nordgaard, K., Julshamn, K., and Schjoensby, H.:Increased serum aluminum in patients with jaunduce. N.Engl.J.Med., 301; 728-729, 1979.

15) Kuijpers, W., and Bonting, S.L.:The cochlear potentials I. The effect of ouabain on the cochlear potentials of the guinea pig. Pflügers Arch.320 ; 348-358, 1970.

16) Thalmann, R., Kusakari, J., and Miyoshi, T.: Dysfunction of energy releasing and comsuming processes of the cochlea. Laryngoscope, 83 ; 1690-1712, 1973.

17) Marcus, D.C., Demott, J.E., Kobayashi, T., Xian-Xi Ge and Thalmann, R.:Specificity of action of vanadate to the organ of Corti. Hearing Res., 5 ; 231-243, 1981.

（受付 $58,3,15$ ) 